Document downloaded from:

http://hdl.handle.net/10251/108352

This paper must be cited as:

Quintana, A.; Alba Fernández, J.; Rey Tormos, RMD.; Guillén Guillamón, IE. (2018). Comparative Life Cycle Assessment of gypsum plasterboard and a new kind of bio-based epoxy composite containing different natural fibers. Journal of Cleaner Production. 185:408420. doi:10.1016/j.jclepro.2018.03.042

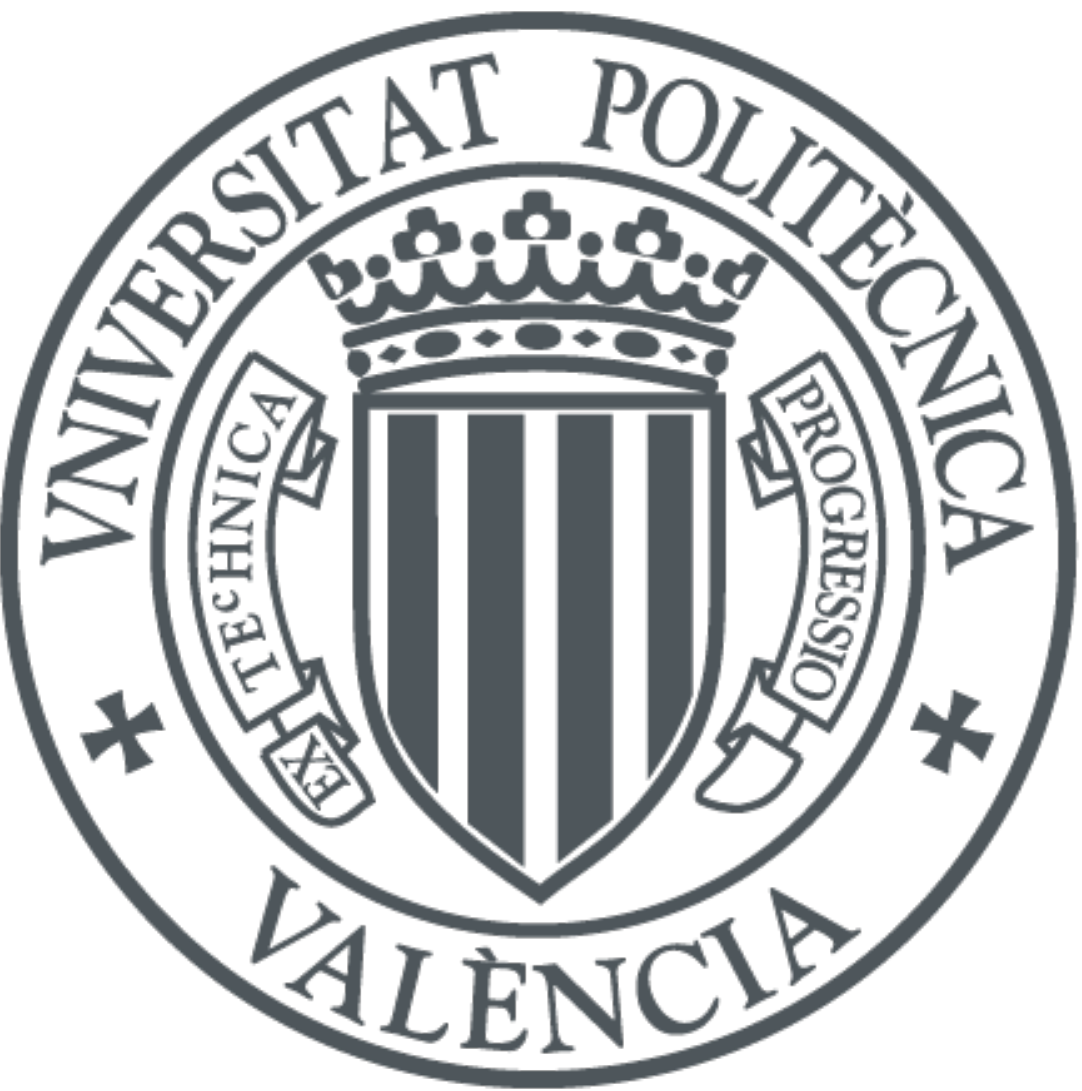

The final publication is available at

https://doi.org/10.1016/j.jclepro.2018.03.042

Copyright Elsevier

Additional Information 


\section{Comparative Life Cycle Assessment of gypsum plasterboard and a new kind of bio-based epoxy composite containing different natural fibers}

\section{Abstract}

A comparative LCA from cradle to grave between traditional plasterboard, for drywall applications, and different composite boards, made by natural fiber and a bio-based epoxy resin (Supersap CLR), was carried out. The goal of the study was to determine whether the composites based on such a resin combined with natural fibers could be an eco-friendly alternative to plasterboard in the building sector. Moreover, the impacts related to each of the fibers used are also assessed separately from cradle to gate in order to get a better understanding of its influence. Both the results obtained through the IPC.GWP 100a method and the recipe endpoint show a remarkable difference between the plasterboard and all the different composites, the composites offering a $50 \%$ reduction in the $\mathrm{CO}_{2}$ emissions. The calculations performed regarding the impacts related to the different fibers showed only small differences between them.

\section{1.-Introduction}

Nowadays, there is evidence that supports the existence of global warming (Cox et al., 2000)(Le Quéré et al., 2015)(Parmesan and Yohe, 2003). This situation is making society become increasingly aware of the imminent danger that global warming may cause (Thomas et al., 2004). This change in attitude can not only be observed in the general population but also in new international and even regional laws, norms and regulations. All of them reflect this change in mentality with a common main objective: to avoid the occurrence of global warming or if not possible, to reduce drastically its effects.

Every industry field is undergoing deep change in their production process in order to succeed in making the least damaging products they can. We can consider the construction industry to be especially sensitive in this matter due to the enormous amounts of raw materials required to perform any activity in such a field (GonzálezVallejo et al., 2015). The search for ecological materials becomes crucial in meeting this necessity (Cabeza et al., 2014). Natural fibers are on the spotlight of many companies and scientific studies (Alves et al., 2010)(John and Thomas, 2008), with the common idea that its use as a raw material results in low environmental impacting products. But are the natural fiber made materials really less detrimental to the environment? In order to answer this question, it is necessary to analyze all the processes involved in the life cycle of each particular material from the moment the manufacturing is started until the end of life of the resulting product. This methodology is known as the Life Cycle Assessment (LCA) defined in the international ISO 14040, 2006 norm (International Organization for Standardization, 2006).

Until now, several studies have been carried out demonstrating that the use of natural fibers in relation with traditional materials, implies a reduction in the impacts associated with the automobile industry (Pegoretti et al., 2014)(La Rosa et al., 2013)(Cicala et al., 2016), the electronics industry (Deng et al., 2016) and in other areas as well. However, 
only a few studies have been performed concerning a product or a material with direct application to the building sector (Asdrubali et al., 2012).

\section{1- Context of the case study}

The case study presented in this paper was conducted within a larger project, based on the research of new materials and products applicable to the building industry with a low environmental impact and the study of its acoustic and thermal properties as well. The project is developed in Spain by the Polytechnic University of Valencia (UPV), so all the estimated consumption of energy related to transportation and electricity mix were made considering the necessary steps to manufacture the materials in such a country. Despite this fact, the study is easily applicable anywhere else as seen in the subsequent sections.

The building sector in Spain is based on materials extracted from quarries such as clay for bricks or tiles, plaster for drywalls, concrete for the structure or even stone for products like mineral wool. The vast majority of construction projects use these kinds of materials whose extraction from the land implies a huge environmental impact on the ecosystems (Rodríguez et al., 2015). The quest for alternatives to brick and plaster is key to assure a sustainable development and evolution in such a market anchored to the traditional products which sees any use of new materials with skepticism.

In order to counter this skepticism, it is necessary to prove to companies, without any doubt, that the alternatives offered guarantee not only equivalent mechanical, acoustic and thermal properties, but also that they bring noticeable improvement for the environment, therefore adding value to their products. The use of these alternatives opens a whole new market of eco-friendly consumers for the company. Currently the most highly trusted certificates for green construction such as BREAM and LEED reward the use of those kinds of materials.

\section{Methodology}

\section{1- Goal and scope definition of the study}

The main goal of this study is to perform a comparative Life Cycle Assessment between two construction oriented materials. One of them is the traditional gypsum plasterboard, widely used all over the world as a drywall component, and a new kind of epoxy composite, produced in the UPV laboratory, thought to be an alternative to the previous one.

The epoxy composites produced have an epoxy-made matrix with ecological content known commercially as Supersap ("Entropy Resins delivers sustainable composites," 2011) and natural fibers of different kinds (flax, hemp, coir, jute and shredded cotton fibers) as the solid filling. The objective pursued is to determine, with a quantitative analysis, if the use of these composites may suppose an ecological alternative to traditional plasterboard.

The motivation for this study comes from a recent industrial production innovation made a few years ago by the company Entropy Resins in creating the epoxy resin Supersap, which is partially made out of ecological materials. The company claims to reduce $\mathrm{CO}_{2}$ emissions to around a $50 \%$ with respect to regular epoxy resins ("Entropy 
Resins delivers sustainable composites," 2011). An LCA of the environmental impacts generated by composites made using Supersap and natural fibers compared to those generated by epoxy with glass fiber has already been performed (Angela Daniela La Rosa et al., 2014). The study included a comparison between the impacts generated by Supersap epoxy resin and Petroleum based epoxy resin (depicted in Table 1). That comparison shows that the impacts generated by Supersap are significantly lower in most categories. In addition, a comparative LCA using Supersap in building envelope solutions was carried out with special attention to thermal conductivity(A. D. La Rosa et al., 2014). However, composites made using Supersap have not been compared to gypsum plasterboard, yet.

This comparative LCA is performed from cradle to grave, meaning that the processes considered are the ones from the beginning of the production of every material used, going through each process of manufacturing until the end of life of the final product, in this case its landfilling. As it is explained in the following sections, the use phase in the studied materials won't produce any impact over the environment.

\section{Table 1}

Potential environmental impacts associated to 1 tonne of petroleum-based epoxy resin and 1 tonne of plant-derived Supersap Entropy resin

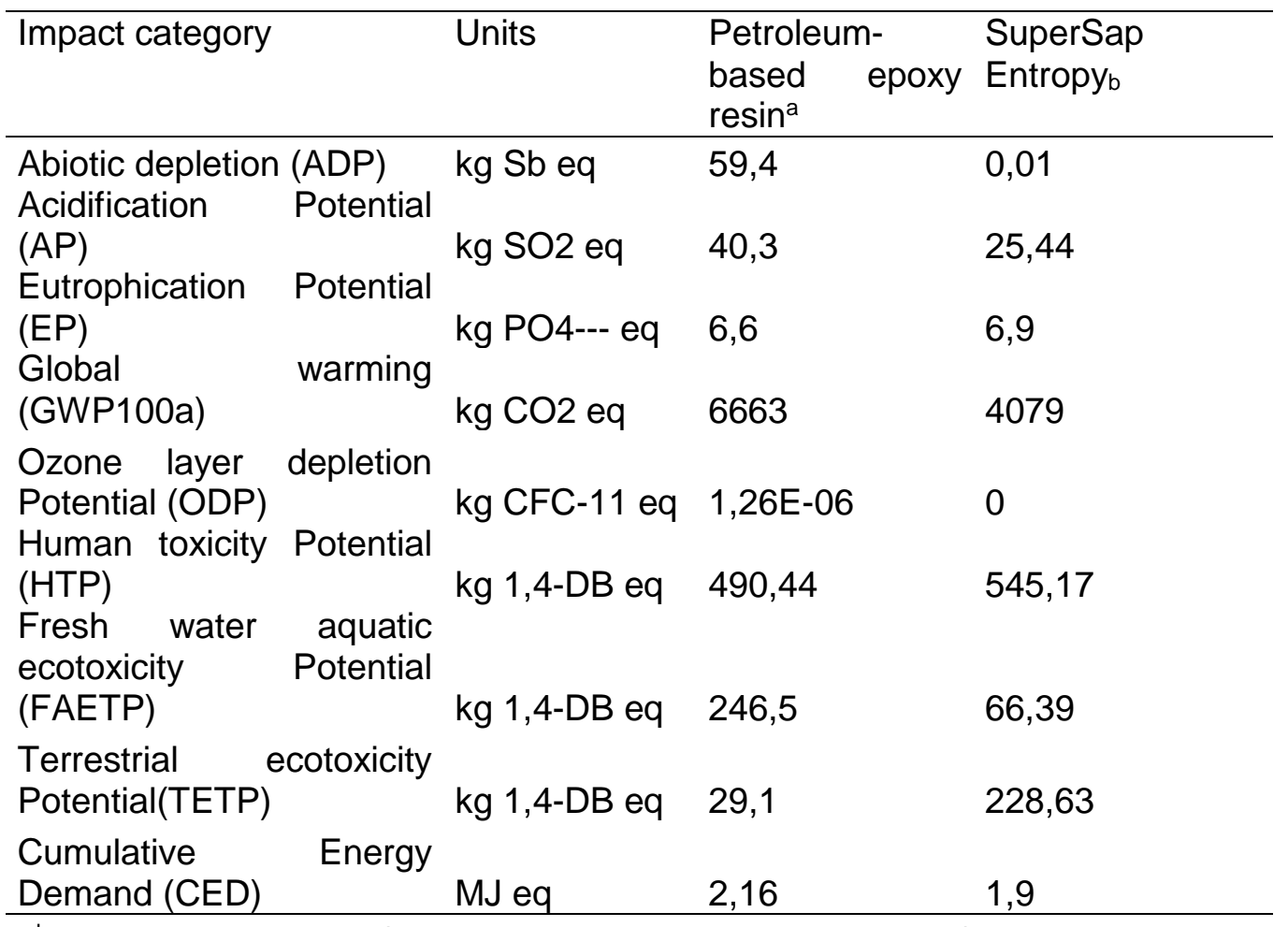

a,bValues published by (Angela Daniela La Rosa et al., 2014)

\section{2- $\quad$ Functional unit}

The functional unit considered in this study is $1 \mathrm{~m}^{2}$ of material, each material having a slightly different thickness. This difference in volume between them is not considered to be relevant because they accomplish the same task as a part of a drywall system regardless of their thickness. 


\section{3- Inventory analysis}

An Inventory analysis based on the model described in the subsequent sections has been performed following the framework provided by the ISO 14040 (International Organization for Standardization, 2006). The objective of an inventory analysis is to account for every activity, raw material and process that can impact the environment. For that purpose, reliable data has been collected to describe the mentioned model. The tool used to model the Life Cycle Inventory is the software Simapro 8.3.0.0, the last version of one of the most popular software programs used for LCA calculations.

In relation to the geographical representativeness, the energy and production data used is adapted to the European market. All the transportation impacts are considered in the scope of the study, as shown in table 2.

\section{Table 2}

Transportation processes

\begin{tabular}{lll}
\hline Raw material & $\begin{array}{l}\text { Means } \\
\text { transportation }\end{array}$ & of \\
\hline Flax fiber & Lorry 16 metric tons & 250 \\
Jute Fiber & Transoceanic ship & 6711 \\
& Lorry 16 metric tons & 100 \\
Coir & Transoceanic ship & 3584 \\
& Lorry 16 metric tons & 350 \\
Hemp Fiber & Lorry 16 metric tons & 450 \\
Recycled & Lorry 16 metric tons & 50 \\
shredded & & \\
cotton fiber & & \\
Epoxy resin & Transoceanic ship & 6000 \\
& Lorry 16 metric tons & 250 \\
\hline
\end{tabular}

\subsection{1- Data quality}

The production data of Supersap Manufacturing was extracted from the technical documentation offered by the company. The data related to the proportions of fibers and epoxy was obtained during the manufacturing process of the epoxy boards. The rest of the data used comes from the Ecoinvent V3 database (Ecoinvent, 2016). The Ecoinvent database, a not-for-profit association founded by institutes of the ETH Domain and the Swiss Federal Offices, is one of the most comprehensive international Life Cycle Inventory ( $\mathrm{LCl}$ ) databases. The available data in it covers processes from a wide range of industries classified by country such as chemical, building sector, agriculture, transport, energy and so on. Moreover, its data is highly reliable due to its peer review process, in which any data is revised by an LCA expert before being approved to be in the database(Pascual-González et al., 2016). Ecoinvent is used in many LCAs all over the world and with the release of the V3 and recently V3.1 it expands the already extensive capabilities it had in previous versions and its transparency (Wernet et al., 2016). 


\subsection{2- Production phase model}

\subsubsection{1- Production process of gypsum plasterboard}

Gypsum plasterboard is made out of a plaster core covered on its two sides by a cellulose layer. The production process goes as follows: The gypsum rocks are extracted from the quarry having approximately a maximum diameter of $5 \mathrm{~cm}$, then the gypsum rocks are transported to a production factory where they are grinded into powder and heated up to $160 \stackrel{\circ}{\circ}$. During this process, the gypsum loses about a $70 \%$ of its moisture which turns into stucco. Then, it becomes slurry when mixed with water and some chemical substances. Afterwards it is poured over a big cellulose layer which is unrolled onto a long board machine. Another layer of paper is unrolled on top of the slurry and then it goes through a system of different rolls compacting the core to the proper thickness. A few minutes later the slurry begins to harden and is prepared to be cut to the desired size. The last step consists in putting the board into an oven to remove the remaining moisture. The production process is summarized in Figure 1. The main impacting steps during the manufacturing process are specified in table 3 . A comparison between the impacts produced by $1 \mathrm{~kg}$ of plasterboard and $1 \mathrm{~kg}$ of petroleum-based epoxy resin is depicted in Table 4.

\section{PLASTERBOARD MANUFACTURING PROCESS}

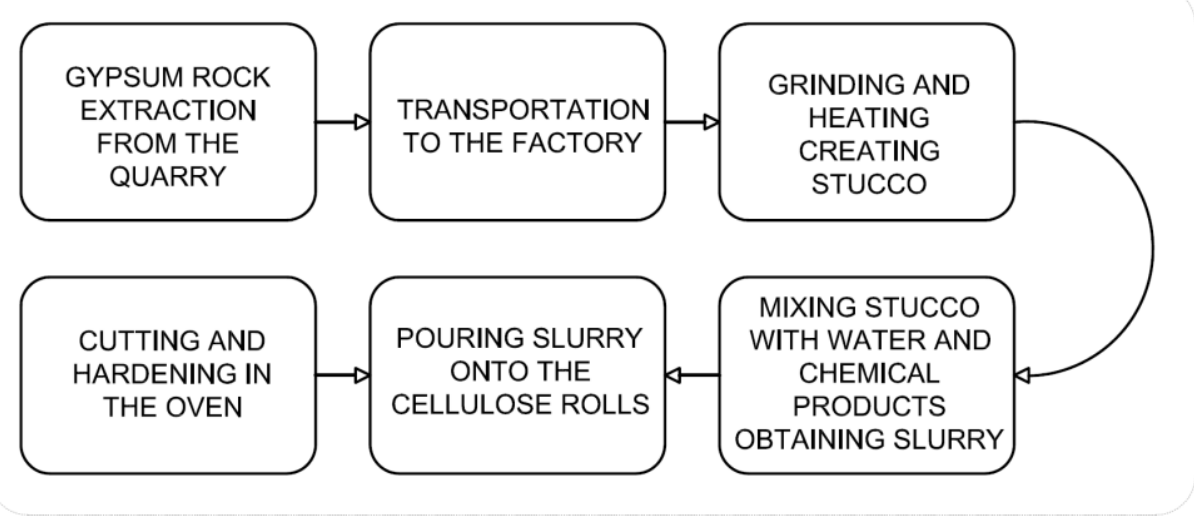

Fig.1. Plasterboard manufacturing process

\section{Table 3}

Inventory of the main impacting steps for $1 \mathrm{k}$ of gypsum plasterboard

\begin{tabular}{llll}
\hline & Quantity & Unit & $\mathrm{kg} \mathrm{CO} 2 \mathrm{eq}$ \\
\hline Transport, freight lorry & 0,117 & $\mathrm{tkm}$ & 0,0155 \\
Stucco & 0,811 & $\mathrm{~kg}$ & 0,066 \\
Folding boxboard/chipboard & 0,0484 & $\mathrm{~kg}$ & 0.103 \\
Organic bonded boards & $1,67 \mathrm{E}-11$ & $\mathrm{p}$ & 0,00186 \\
Electricity, medium voltage & 0,5991 & $\mathrm{MJ}$ & 0,124 \\
Industrial heat & 2,521 & $\mathrm{MJ}$ & 0,2463 \\
\hline
\end{tabular}




\section{Table 4}

Comparison between $1 \mathrm{~kg}$ of Plasterboard and $1 \mathrm{~kg}$ of Petroleum based epoxy resin

\begin{tabular}{|c|c|c|c|}
\hline Impact category & Units & $\begin{array}{l}\text { Gypsum } \\
\text { plasterboard }\end{array}$ & $\begin{array}{l}\text { Petroleum based } \\
\text { epoxy resin }\end{array}$ \\
\hline Abiotic depletion & $\mathrm{kg} \mathrm{Sb} \mathrm{eq}$ & 2,52E-07 & 1,19E-06 \\
\hline Abiotic depletion (fossil fuels) & MJ & 29,996372 & 122,42557 \\
\hline Global warming (GWP100a) & kg CO2 eq & 2,1386249 & 6,9448216 \\
\hline Ozone layer depletion (ODP) & kg CFC-11 eq & $1,63 E-07$ & $1,41 E-08$ \\
\hline Human toxicity & kg 1,4-DB eq & 0,048522658 & 0,68101491 \\
\hline Fresh water aquatic ecotox. & kg 1,4-DB eq & 0,003153629 & 0,89204571 \\
\hline Marine aquatic ecotoxicity & kg 1,4-DB eq & 53,231855 & 4848,7284 \\
\hline Terrestrial ecotoxicity & kg 1,4-DB eq & 0,00281531 & 0,029100246 \\
\hline Photochemical oxidation & $\mathrm{kg} \mathrm{C} 2 \mathrm{H} 4 \mathrm{eq}$ & 0,000335308 & 0,001196045 \\
\hline Acidification & kg SO2 eq & 0,005004837 & 0,041101898 \\
\hline Eutrophication & kg PO4--- eq & 0,000804968 & 0,006681138 \\
\hline
\end{tabular}

\subsubsection{2- Production process of the epoxy composite boards}

All the composite boards analyzed have the usage of Supersap Epoxy resin in common, each one of them containing a different kind of natural fiber. The materials used and its cultivation process are summarized as follows (Figures 2, 3):

Flax: After harvesting, the first step is retting; a method used to dissolve much of the cellular tissues and pectin surrounding the fiber. Afterwards, the stems have to be submitted to a process called scutching, in which the stems are crushed by a pair of fluted rollers and beaten by a rotating blade to make the shive (the inner body tissue) fall off. A big variety of products can be obtained by scutching, such as long and short fibers, shive, flakes and seeds. The scutched fibers are then hackled to remove the remaining impurities and wood particles, getting as a result slivers and hackled tows. Once this process has finished, the slivers can be twisted into yarn using one of two different methods: wet spinning or dry spinning. Wet spinning involves further processes such as roving or bleaching and is generally used to produce fine textiles whereas the dry spinning is a much more simple process carried out by applying the spinning directly to the long fibers. As a result, using the dry spinning we get coarse and less expensive fibers and the use of chemical products is reduced. Considering that the fibers used in a composite material do not need to be particularly pleasant to the eye, the most suitable method for this particular application is the dry spinning process, therefore excluding the bleaching and roving (Le Duigou et al., 2011).

Hemp: the hemp fiber is produced from Cannabis Sativa varieties with lower cannabinoid content and with higher fiber proportion than other members of the species. After the sowing and cultivation period, the plants are harvested as soon as 
the male plants begin to exude pollen. Afterwards the dew retting process begins; the stems are placed on the floor for several weeks where due to the effect of the sun and the wind the pectin rots baring the bast fibers. There are further sophisticated processes using chemical products if needed, but they are not considered for this case study. The final separation of the fiber is accomplished in a way similar to the flax process, starting by the breaking operation in which the wood portion of the straw is broken mechanically or manually, followed by the scutching process removing the wood particles called shive and finally hackling for further elimination of the shive and short fibers. Nowadays this whole process is easily made using modern machinery. Once the fibers are separated and bundled together the spinning operation begins.

Jute: The jute cultivation and processing to obtain fiber is very similar to the ones used for flax and hemp, all of them depicted in Figure 2. The manufacturing steps needed in order to obtain the fiber are roughly the same: Harvesting, retting, breaking, scutching, hackling and spinning.

FIBER PRODUCTION. Flax, jute and hemp

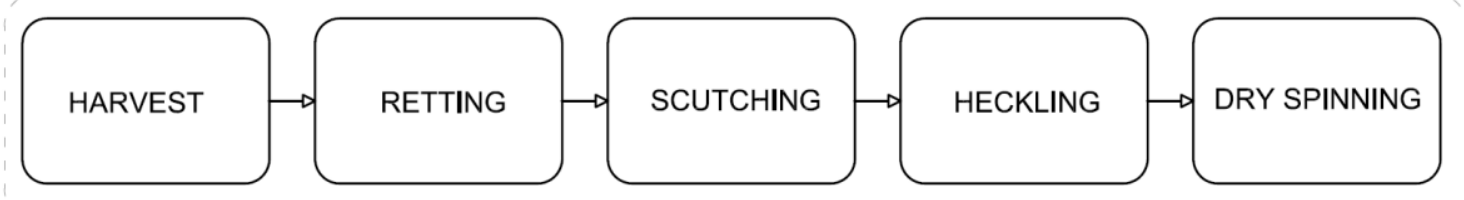

Fig.2. Flax, jute and hemp manufacturing process

Coir: as opposed to the previously mentioned fibers, which are obtained from medium to small size plants, coir is obtained from the exterior husk of the coconut tree fruit. The coconut tree can reach 30 meters tall, making the harvesting process more complex than in smaller plants or trees. The gathering of the coconuts can be done by climbers, from the ground using bamboo reeds or even with trained monkeys. Once the coconut is harvested, it is dehusked impaling it with a steel-tipped spike. After carrying out this processes the next steps are the same as seen previously. It starts with retting, followed by breaking, scutching, hackling and finally spinning. The processes followed are depicted in Figure 3

FIBER PRODUCTION. Coir

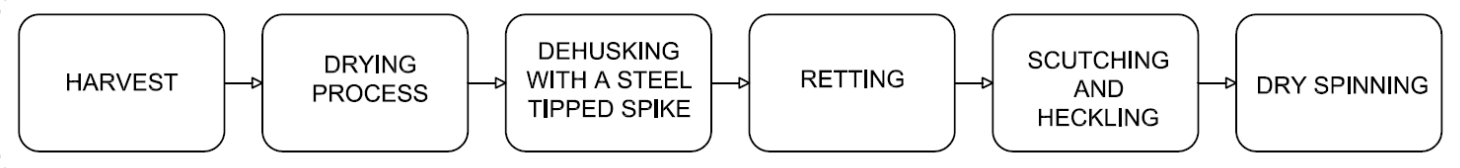

Fig.3. Coir manufacturing process

Recycled shredded cotton: this material is completely different from the rest, being the only one in this study which comes from recycled material obtained from textile residue. The residues are collected and transported to big processing plants where they are classified depending on the content and its destination. Once classified, the waste is transported to a second plant where, in this case, the residue is shredded and compacted obtaining shredded cotton fiber. The processes are represented in Figure 4. The inventory of each fiber used is depicted in table 5. 
FIBER PRODUCTION. Shredded fibers

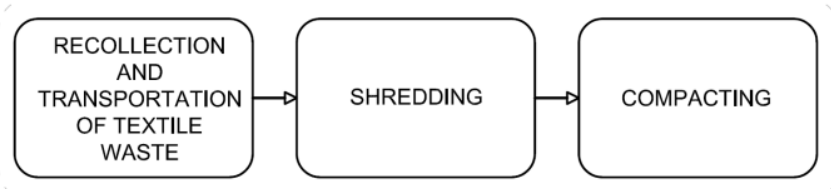

Fig.4. Shredded cotton fiber manufacturing process

Table 5

Inventory of main impacting steps for $1 \mathrm{~kg}$ of fiber

\begin{tabular}{|c|c|c|c|}
\hline & Quantity & Unit & $\mathrm{kg} \mathrm{CO} 2 \mathrm{eq}$ \\
\hline \multicolumn{4}{|l|}{ Jute } \\
\hline $\begin{array}{l}\text { Phosphate fertilizer, as } \\
\text { P2O5 }\end{array}$ & 0,0124 & $\mathrm{~kg}$ & 0,0132 \\
\hline Urea as $\mathrm{N}$ & 0,0311 & $\mathrm{~kg}$ & 0,0982 \\
\hline Irrigation & 0,5806 & m3 & 0,20692 \\
\hline Stalk & 1,7 & $\mathrm{~kg}$ & 0,252 \\
\hline \multicolumn{4}{|l|}{ Hemp } \\
\hline Fertilizing by broadcaster & 38,1 & $\mathrm{~m} 2$ & 0,107 \\
\hline Urea as $\mathrm{N}$ & 0,0189 & $\mathrm{~kg}$ & 0,0598 \\
\hline Irrigation & 0,4095 & m3 & 0,1449 \\
\hline Stalk & 1,7 & $\mathrm{~kg}$ & 0,252 \\
\hline \multicolumn{4}{|l|}{ Cotton } \\
\hline Transport by lorry & 0,229 & $\mathrm{tkm}$ & 0,03188 \\
\hline Transport by train & 0,000684 & $\mathrm{tkm}$ & 0,000118 \\
\hline Irrigation & 0,2539 & m3 & 0,1121 \\
\hline Electricity, low voltage & 0,807 & MJ & 0,2302 \\
\hline Ammonium nitrate as $\mathrm{N}$ & 0,00734 & $\mathrm{~kg}$ & 0,0598 \\
\hline \multicolumn{4}{|l|}{ Coconut } \\
\hline Poultry manure, dried & 0,0624 & $\mathrm{~kg}$ & 0,0311 \\
\hline Urea as $\mathrm{N}$ & 0,00606 & $\mathrm{~kg}$ & 0,0191 \\
\hline Potassium fertilizer as $\mathrm{K} 2 \mathrm{O}$ & 0,00935 & $\mathrm{~kg}$ & 0,00337 \\
\hline Packaging for pesticides & 0,059 & $\mathrm{~kg}$ & 0,0147 \\
\hline Trellis system & 1,68 & $\mathrm{~m} 2$ & 0,107 \\
\hline Irrigation & 0,341 & m3 & 0,1533 \\
\hline $\begin{array}{l}\text { Flax } \\
\text { Phosphate fertilizer, as } \\
\text { P2O5 }\end{array}$ & 0,02 & $\mathrm{~kg}$ & 0,0335 \\
\hline Ammonia liquid & 0,012 & $\mathrm{~kg}$ & 0,0226 \\
\hline Potassium fertilizer as $\mathrm{K} 2 \mathrm{O}$ & 0,0161 & $\mathrm{~kg}$ & 0,00835 \\
\hline Tillage, ploughing & 2,75 & $\mathrm{~m} 2$ & 0,036 \\
\hline Tillage, rotary cultivator & 1,37 & $\mathrm{~m} 2$ & 0,0119 \\
\hline Tillage, harrowing & 1,37 & $\mathrm{~m} 2$ & 0,00979 \\
\hline Fertilizing by broadcaster & 4,12 & $\mathrm{~m} 2$ & 0,0116 \\
\hline Plant protection product & 7,55 & $\mathrm{~m} 2$ & 0,00977 \\
\hline Electricity, low voltage & 2,5 & MJ & 0,294 \\
\hline
\end{tabular}


Supersap Epoxy Resin: The term "epoxy resin" describes a wide variety of thermosetting polymers which share the common characteristic of the primary cross linking caused by the reaction of an epoxide group. Its chemical structure can be thought of as an epoxy, which is a molecule containing a three membered ring consisting of one oxygen atom and two carbon atoms. However, this structure varies depending on the purpose of the final product. This diversity is one of the reasons for the success of epoxy resins in such a wide range of applications (Boyle et al., 2001).

The epoxy class analyzed for this article is Phenolic glycidyl ether. This class of epoxy is produced by the reaction of epichlorohydrin (ECH), which is the key component of the vast majority of commercial epoxy resins, and a phenol group, being the bisphenolA (BPA) the most widely used today(Dusek, 1985). However, it must be taken into consideration that the Supersap resin manufacturing process has some key differences with respect to the conventional epoxy resins, all of them subject to a confidentiality agreement. 
Composite assembly: The composite boards are built using the resin infusion process. This process consists in introducing the resin into a mold using vacuum suction. The resin is introduced through tubes or pipes. Inside this mold the amount of fiber needed for the specific type of board chosen is previously placed. This procedure is one of the most modern methods to manufacture composite materials, presenting several improvements in economic and technical aspects (Hammami and Gebart, 2000). The process described above was conducted in UPV facilities. The mass of every material used in each typology is indicated in table 6 . The physical and mechanical characteristics, measured in the UPV laboratory, are specified in table 7.

\section{Table 6}

Mass per $\mathrm{m}^{2}$

\begin{tabular}{|c|c|c|c|c|c|c|}
\hline Product & & Mass(Kg) & Fiber \% & $\begin{array}{l}\text { Fiber } \\
\text { mass }(\mathrm{Kg})\end{array}$ & Epoxy \% & $\begin{array}{l}\text { Epoxy } \\
\text { mass } \\
(\mathrm{Kg})\end{array}$ \\
\hline Flax board & & 5,08 & 49 & 2,4892 & 51 & 2,5908 \\
\hline Jute board & & 5,08 & 44 & 2,2352 & 56 & 2,8448 \\
\hline Coir board & & 7,61 & 22 & 1,6742 & 78 & 5,9358 \\
\hline Hemp board & & 4,31 & 32 & 1,3792 & 68 & 2,9308 \\
\hline $\begin{array}{l}\text { Shredded } \\
\text { board }\end{array}$ & cotton & 4,89 & 27 & 1,3203 & 73 & 3,5697 \\
\hline
\end{tabular}

Table 7

Physical and Mechanical Characteristics

\begin{tabular}{|c|c|c|c|c|c|c|}
\hline Board & & $\begin{array}{l}\text { Thickness } \\
(\mathrm{mm})\end{array}$ & $\begin{array}{l}\text { Density } \\
\text { (g/cm3) }\end{array}$ & Mass/m2 & $\begin{array}{l}\text { Shore C } \\
\text { Hardness }^{1}\end{array}$ & $\begin{array}{l}\text { Impact } \\
\text { resistance }\end{array}$ \\
\hline Plasterboard & & 12,5 & 0,776 & 9,7 & 47,72 & 14,9 \\
\hline Flax board & & 4,62 & 1,183 & 5,08 & 76,2 & 76,72 \\
\hline Jute board & & 5,1 & 1,084 & 5,08 & 70,2 & 14,09 \\
\hline Coir board & & 8,14 & 1,027 & 7,61 & 64,7 & 5,23 \\
\hline \multirow{2}{*}{$\begin{array}{l}\text { Hemp board } \\
\text { Shredded } \\
\text { board }\end{array}$} & \multirow{2}{*}{ cotton } & 4,24 & 1,146 & 4,32 & 70,07 & 5,71 \\
\hline & & 5,1 & 1,071 & 4,89 & 70,3 & 8 \\
\hline
\end{tabular}

${ }^{1}$ Shore Durometer model Instruments J.Bot 673D (ISO 868:2003). Scale Shore D 30은

${ }^{2}$ Charpy impact test. Pendulum by Metrotec (ISO 179:1993). Scale used: $1 \mathrm{~J}$

\subsection{3- Use phase model}

Considering that there is no difference, during the building construction, between any of the typologies under this study, the only processes that need to be taken into account are those related to transportation. Furthermore, the material once used in the construction does not generate any impact to the environment, being the use phase the less relevant for the analysis of the impacts of building materials. 


\subsection{4- End of life model}

Despite the differences between the gypsum plasterboard and each one of the composite boards, every typology analyzed should reach the end of its life cycle together with the building. For this reason we consider them to have the same durability.

As the end of life scenario, all the materials analyzed are considered for landfilling. This option has been chosen because it is the most common scenario in the current situation of the Spanish construction market. Neither the reuse nor the recycling represent an important percentage in the final disposal of building materials for the moment. The life cycle of the composite boards is summarized in Figure 5.

Considering that this situation may change in the near future, a complete analysis concerning the possibilities of recovering some of the materials at their end of life is advisable for future studies, yet beyond the scope of this one.

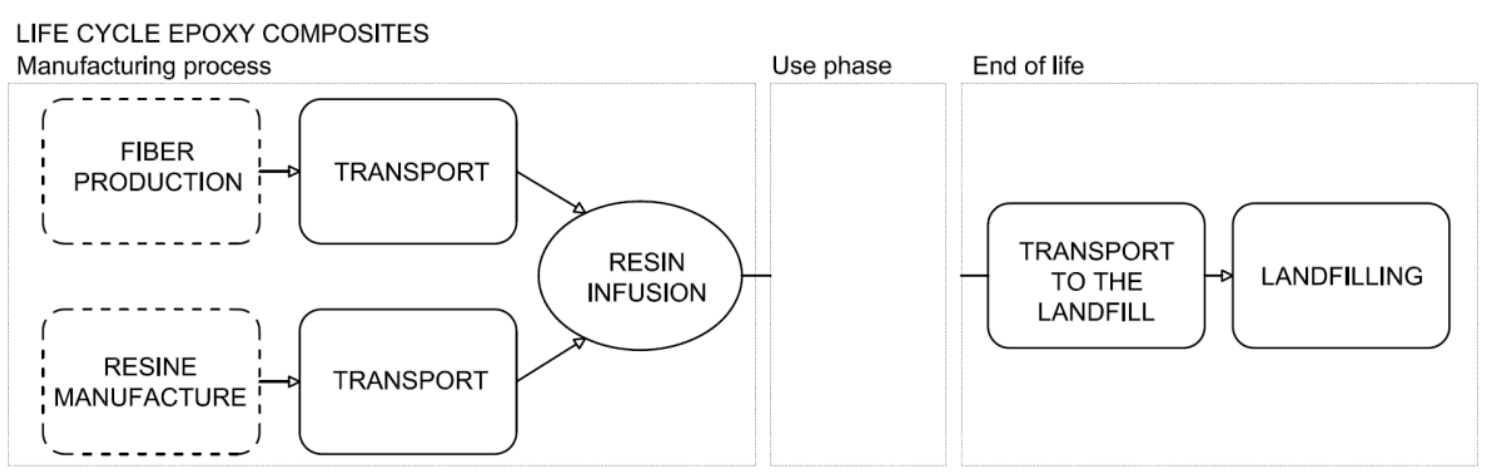

Fig.5. Life cycle of the composite plasterboards

\section{4. - Life Impact Assessment}

\subsection{1- Allocation principle}

Due to the multifunction processes involved in cultivating and manufacturing the fibers, the use of an allocation principle becomes a necessity (Ekvall, 2001). The issue is easily identified for instance in the case of coconut. The environmental burdens of coconut cultivation have to be divided among the different products obtained, such as the coconut water, the pulp and the coir produced with the husk.

Overcoming the difficulties of assigning the proper burdens to each product is not a straight forward issue and has many possible solutions. Each of them has its own benefits and drawbacks. Through the use of the Ecoinvent Database V3.1 it is possible to choose between two main approaches: Consequential and Allocation at the Point of Substitution. The consequential approach is chosen due to its simplicity and reliability. This approach is also considered to be one of the most theoretically correct.(Tommie Ponsioen, 2015). The Consequential System Model is one of the major innovations that were introduced when the Ecoinvent Database V3 was released. This model uses substitution (system expansion) to convert multi-product datasets into single-product datasets. Therefore all the Ecoinvent Database processes chosen are Consequential.

\subsection{2- Evaluation method}


Among all the available methods for performing the life cycle assessment, two of them are selected: The IPCC.GWP 100a used for calculating the greenhouse gas emissions (equivalent $\mathrm{CO}_{2} \mathrm{Kg}$ ) emitted by each material separately and the Recipe Endpoint method. The latter is intended to replace the two most important methods up to this point, the Eco-Indicator99 and the CML 2002 combining the mid-point approach and the end-point approach in a harmonic way (European Commission - Joint Research Centre - Institute for Environment and Sustainability, 2010).

3.-Impact assessment results and discussion

The flowcharts depicted in Figures 6, 7, 8, 9, 10 and 11 show the steps modeled using Simapro with the corresponding carbon dioxide impacts.

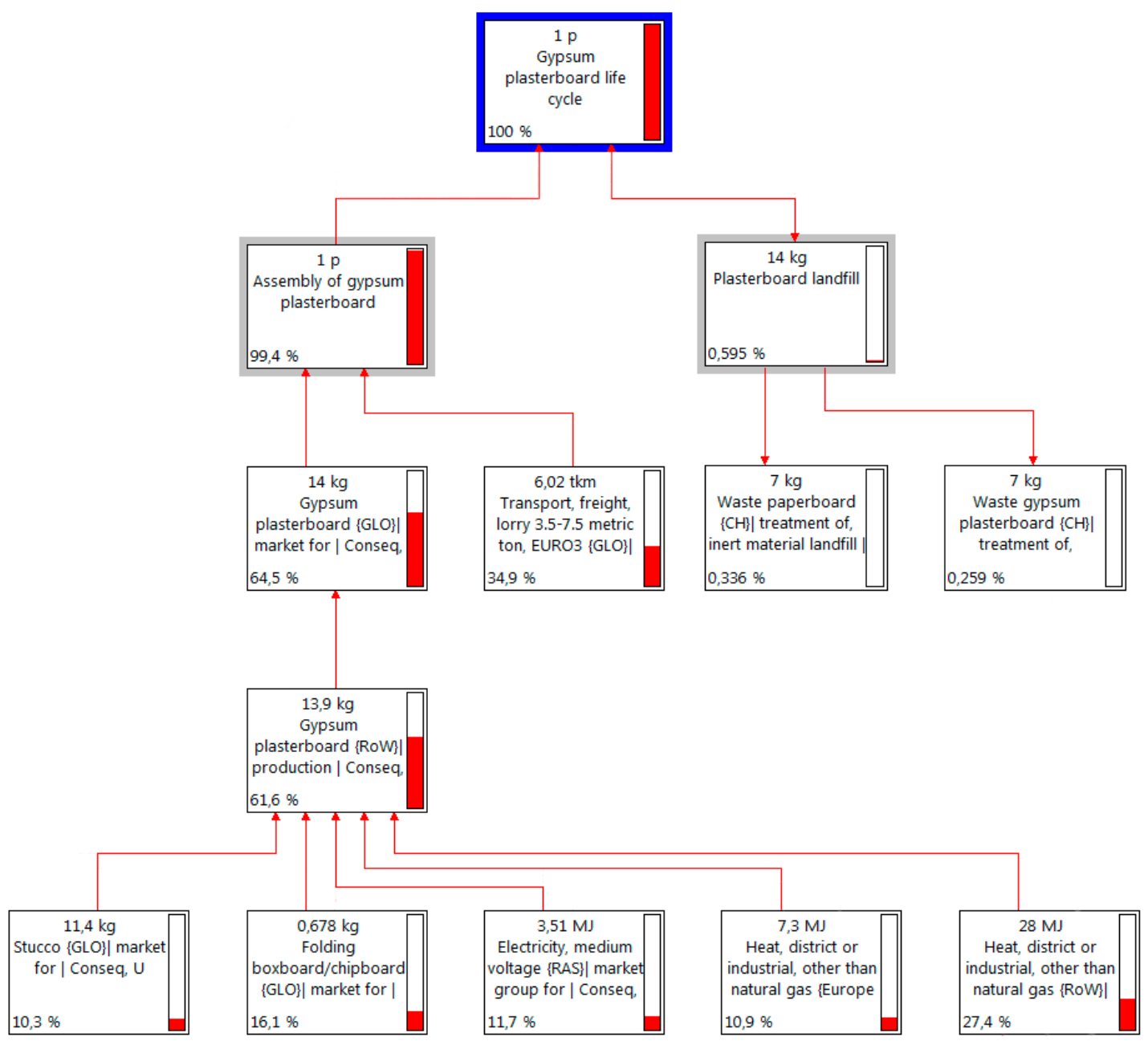

Fig.6. Network of the life cycle of gypsum plasterboard 


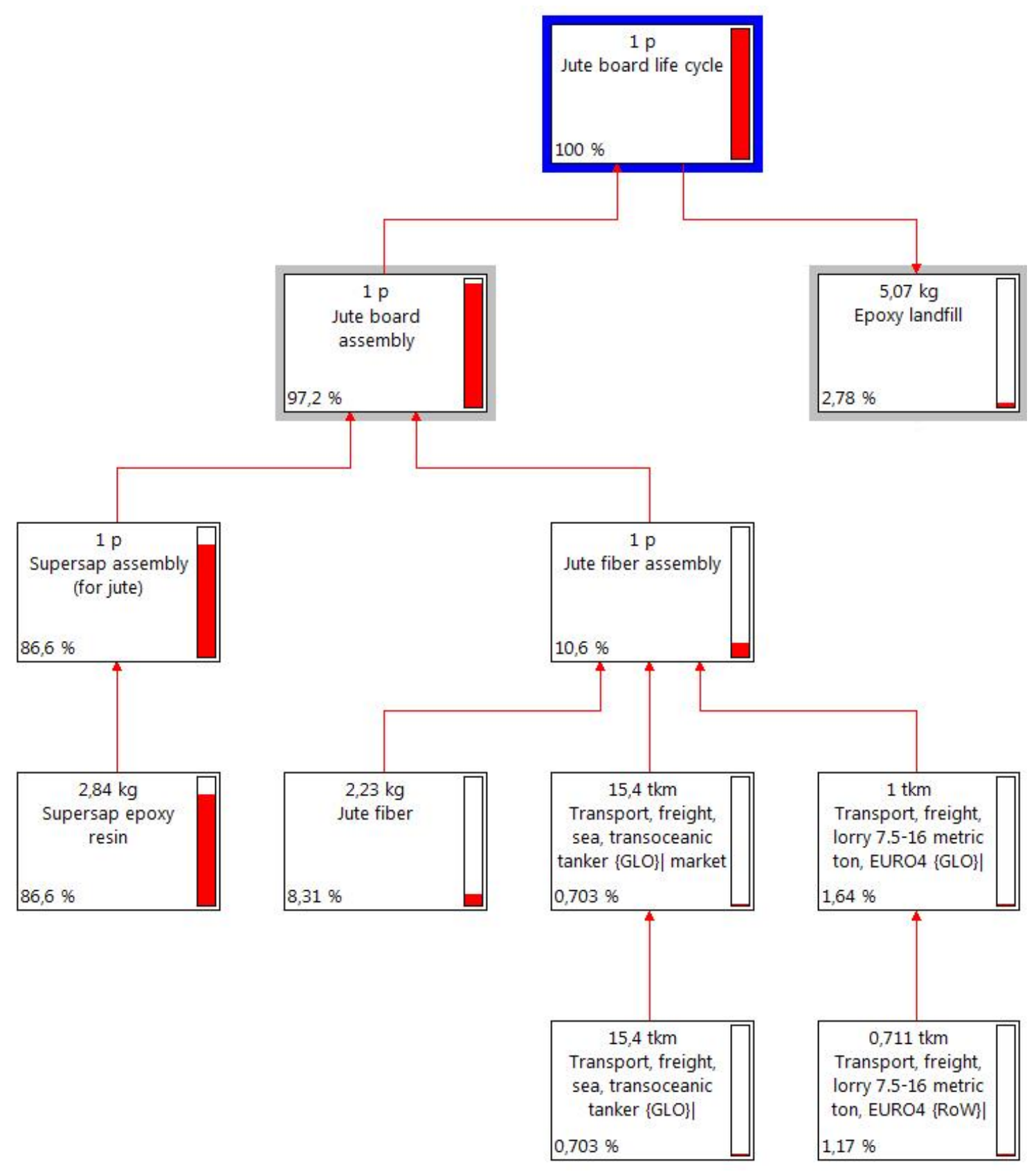

Fig.7. Network of the life cycle of the jute composite board 


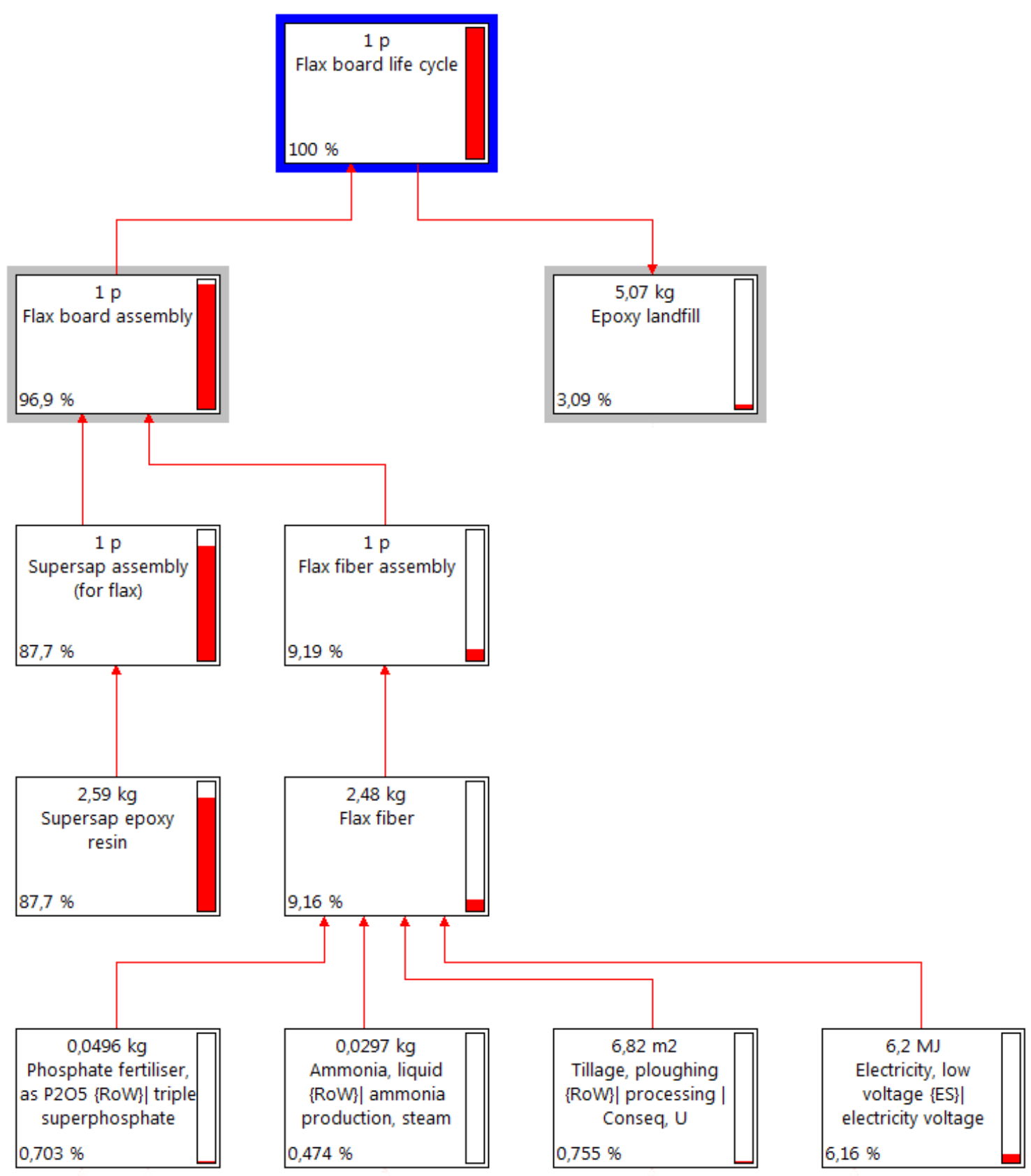

Fig.8. Network of the life cycle of the flax composite board 


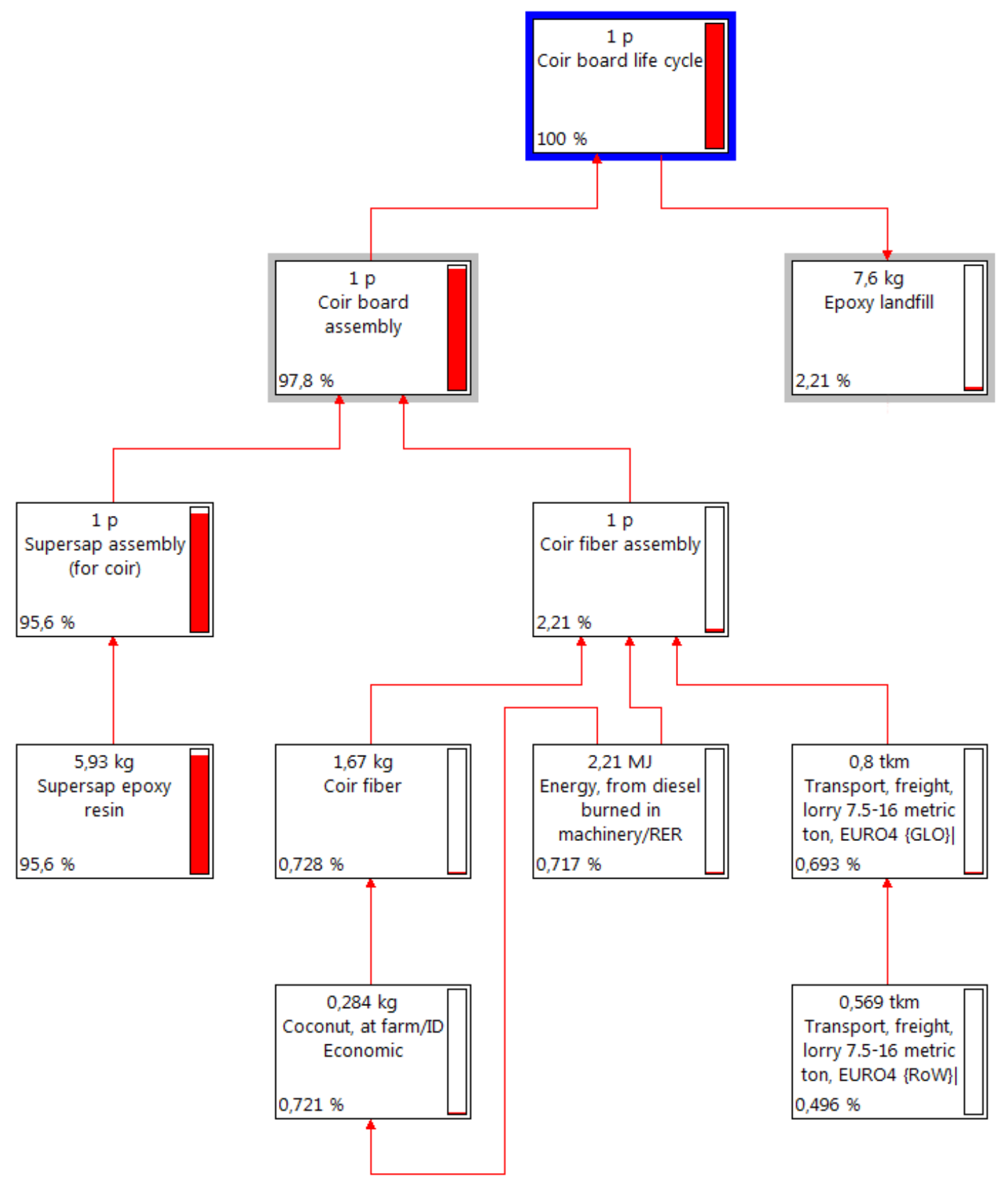

Fig.9. Network of the life cycle of the coir composite board 


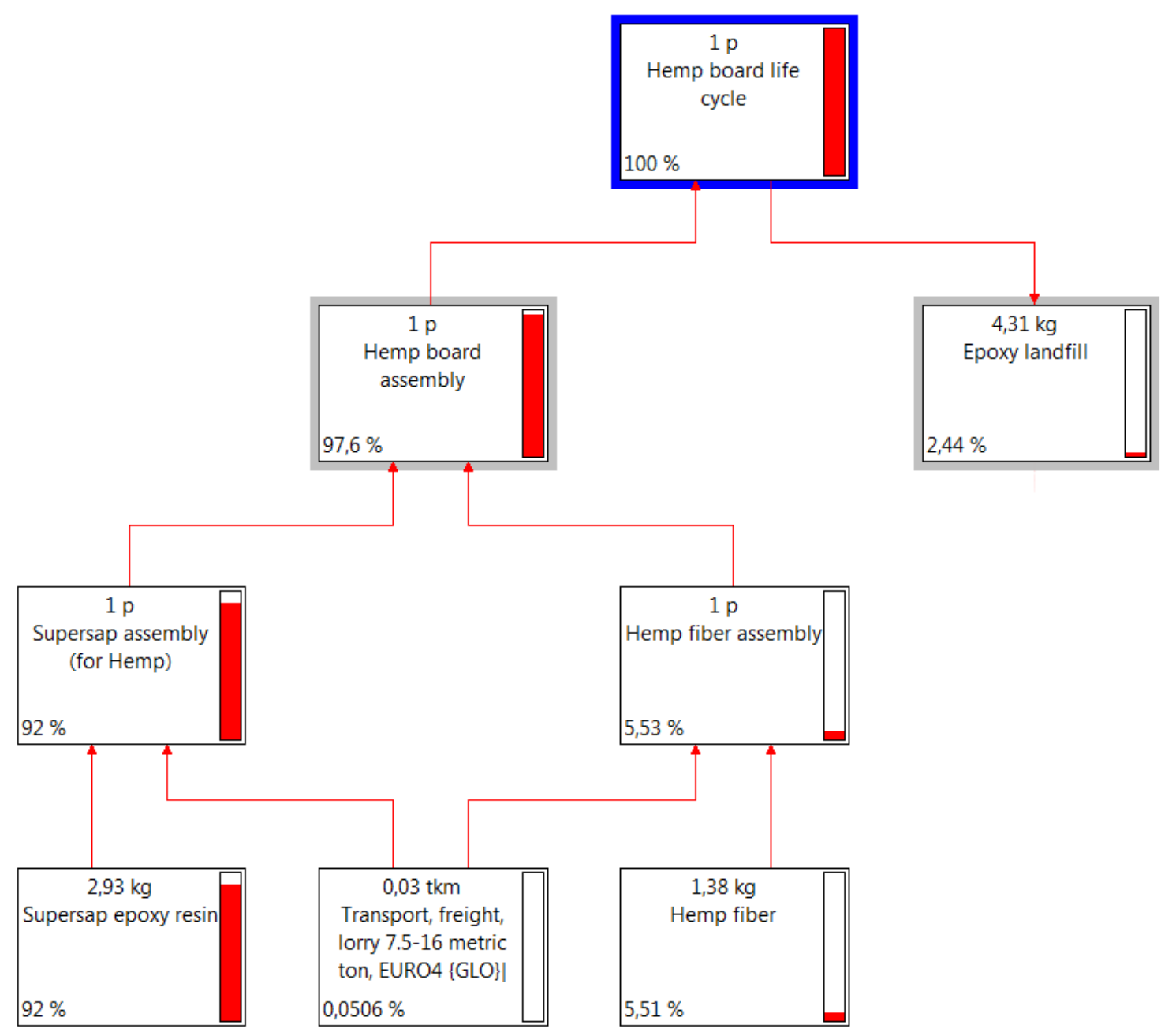

Fig.10. Network of the life cycle of the hemp composite board 


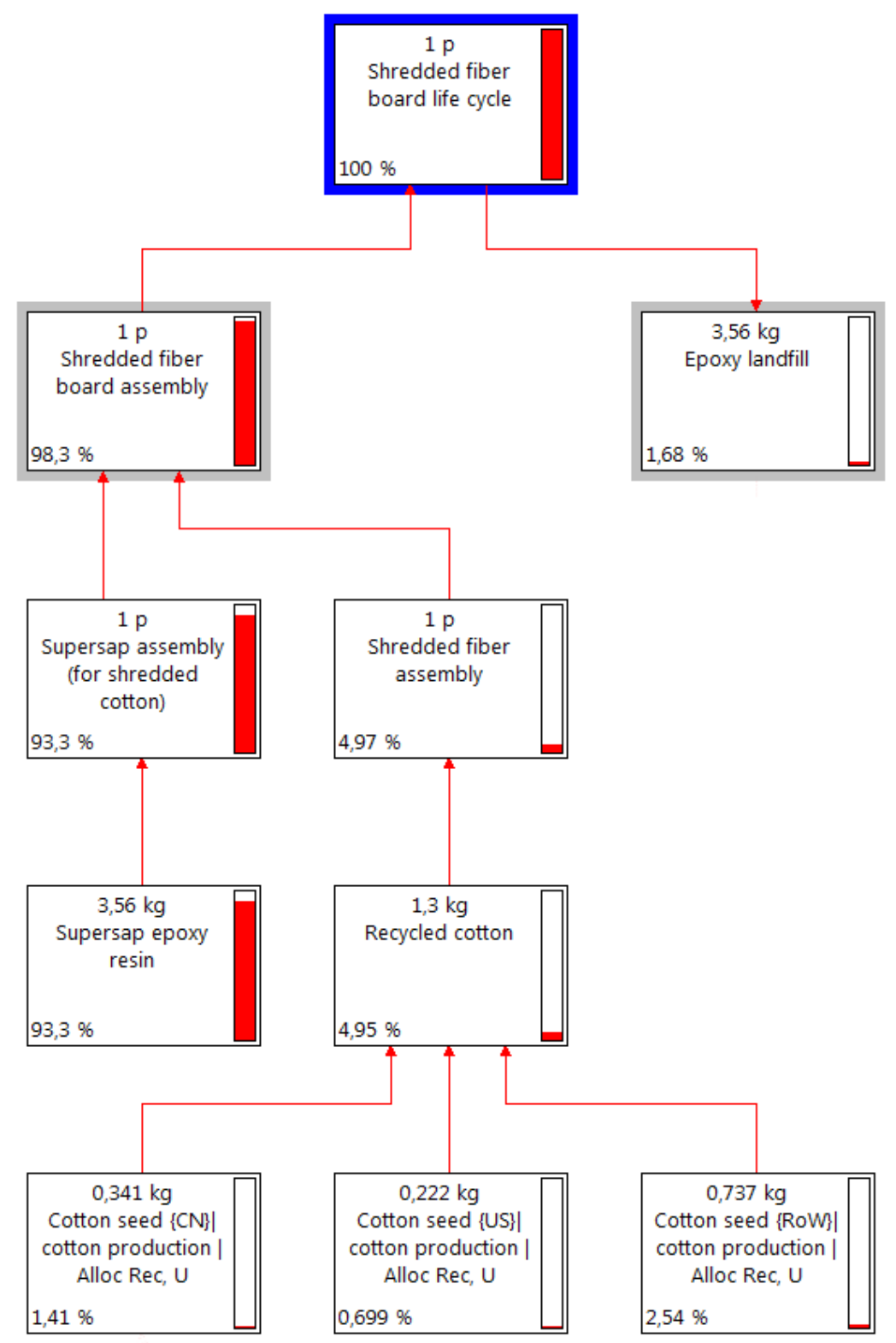

Fig.11. Network of the life cycle of the shredded cotton composite board

\section{1- IPCC.GWP 100a method comparative results. Carbon Dioxide emissions}

As shown in Fig. 12, all the composites except the coir board have considerably lower carbon emissions than the gypsum plasterboard. The results show more than a $50 \%$ reduction in the $\mathrm{Kg} \mathrm{CO}_{2}$ equivalent in the case of flax. The results obtained with the coir board are almost as high as the gypsum plasterboard. The reason why the impacts are superior in the case of coir is because the quantity of Supersap per square meter is much higher (Table 6). Comparing the rest of the composites, the results are quite similar with small differences such as the flax composite emissions being slightly lower. That lower $\mathrm{CO}_{2}$ emission is due to a higher proportion of fiber in its composition. 


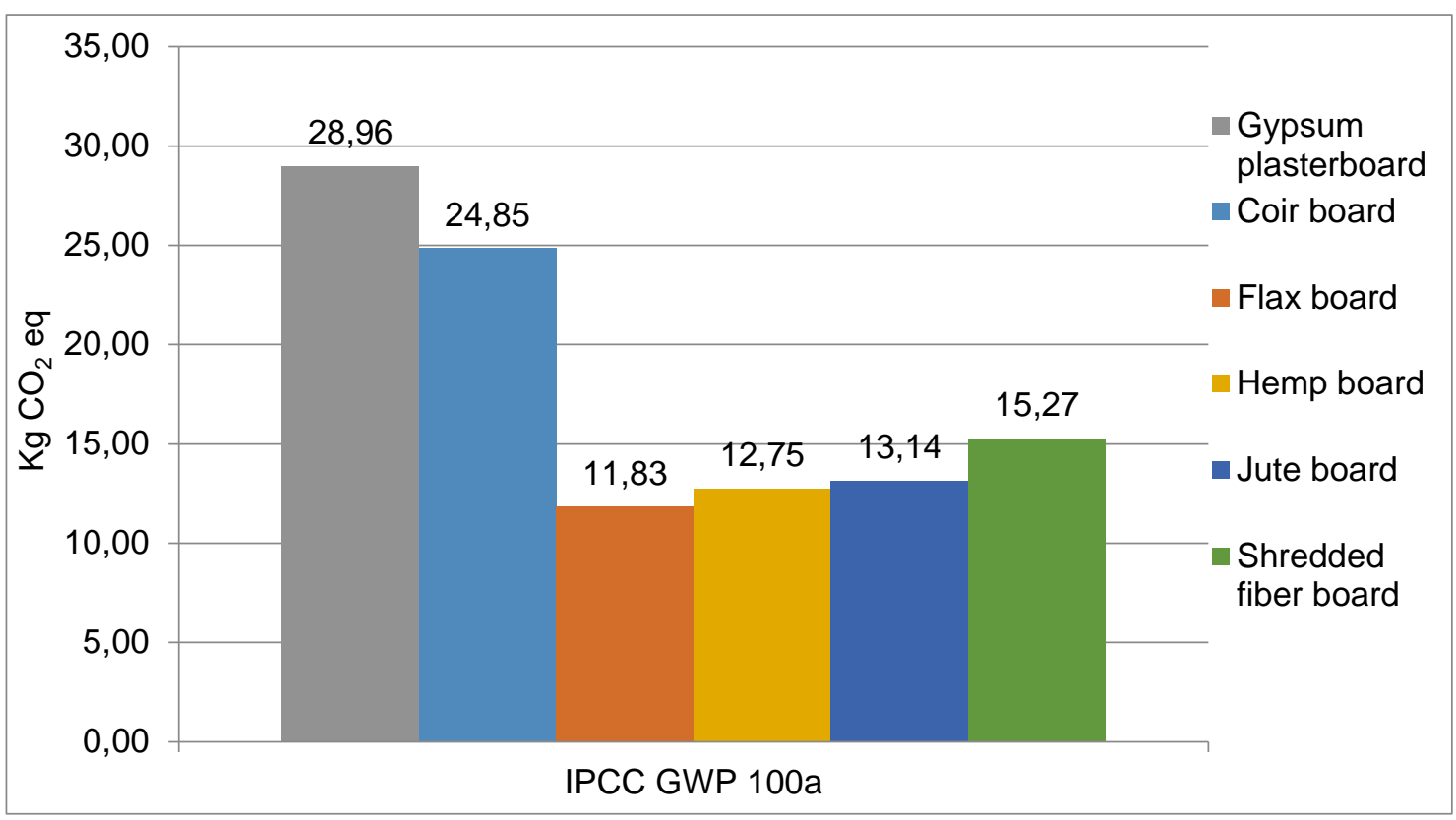

Fig.12. Comparative assessment of the carbon dioxide emissions by $1 \mathrm{~m}^{2}$ of material 
3.2-Recipe Endpoint method comparative results

Using the Recipe Endpoint method, the results of seventeen different impact categories are obtained separately. As shown in Fig. 13, the gypsum plasterboard and the coir board have the higher impact result in fifteen of the seventeen categories studied. The only categories were the score is not superior are Terrestrial Acidification and Agricultural Land Occupation. In those two categories the Jute board stands out as the most impacting material.

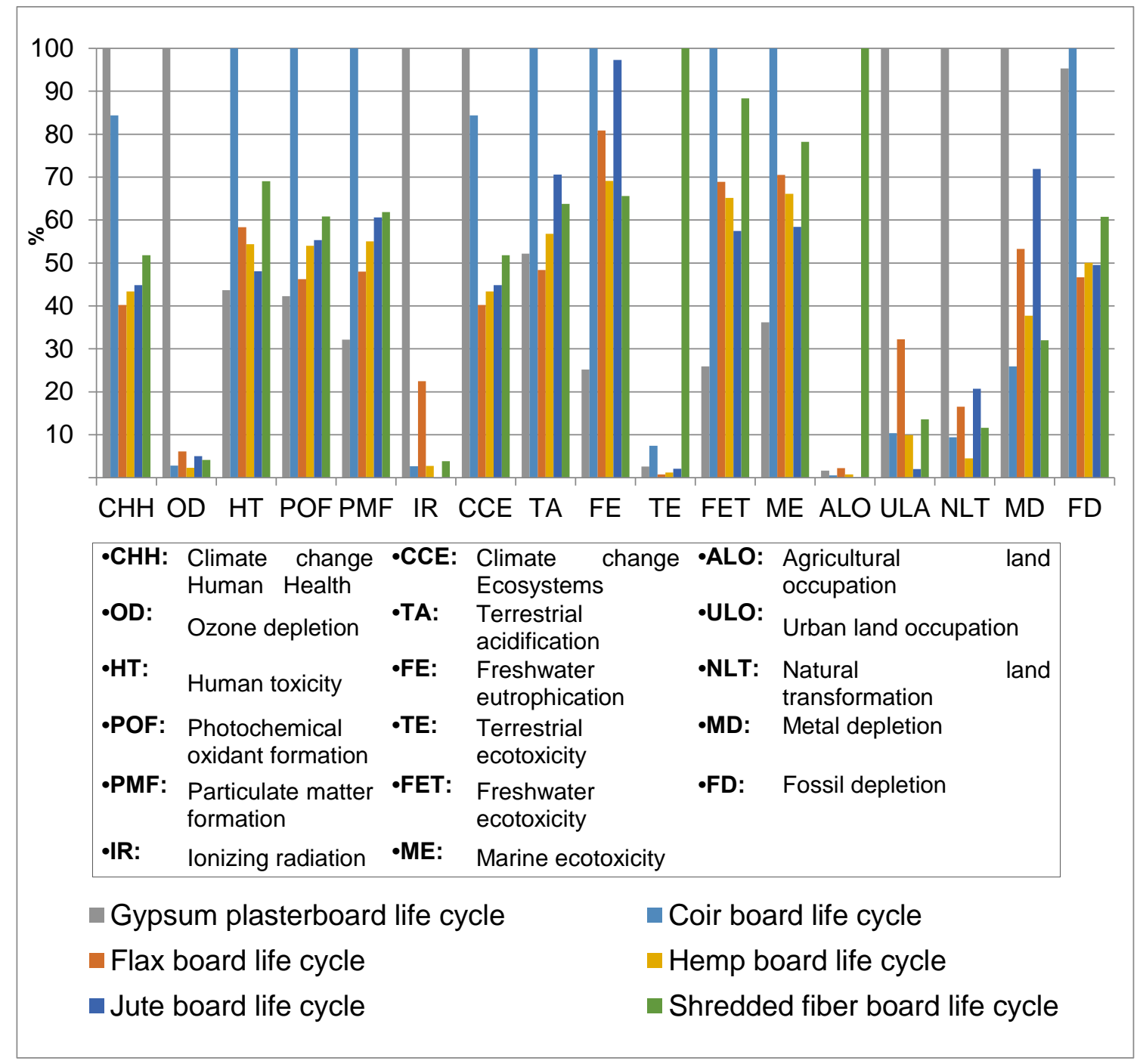

Fig.13. Characterization using the Recipe Endpoint $(\mathrm{H})$ method. Comparative analysis of the environmental impacts produced by a $1 \mathrm{~m}^{2}$ board. 
With the purpose of offering a global impact score for each material, the categories are summarized into three main aspects: Ecosystems, Human Health and Resources. In order to add up together all these different categories, all of them had to be submitted to three processes performed using Simapro: impact evaluation, normalization and weighting. Once these processes are completed, these three categories, obtained by the addition of the others, can also be added together obtaining a global result of the impact of each material. As shown in Fig.14 the results are significantly lower in the composites than in the gypsum plasterboard, with a difference of around 40 to 50 per cent depending on the natural fiber used. The only exception is the coir board, which has the highest impact among all the materials studied. Those high impacts coincide with the coir composite being the one with the higher Supersap content.

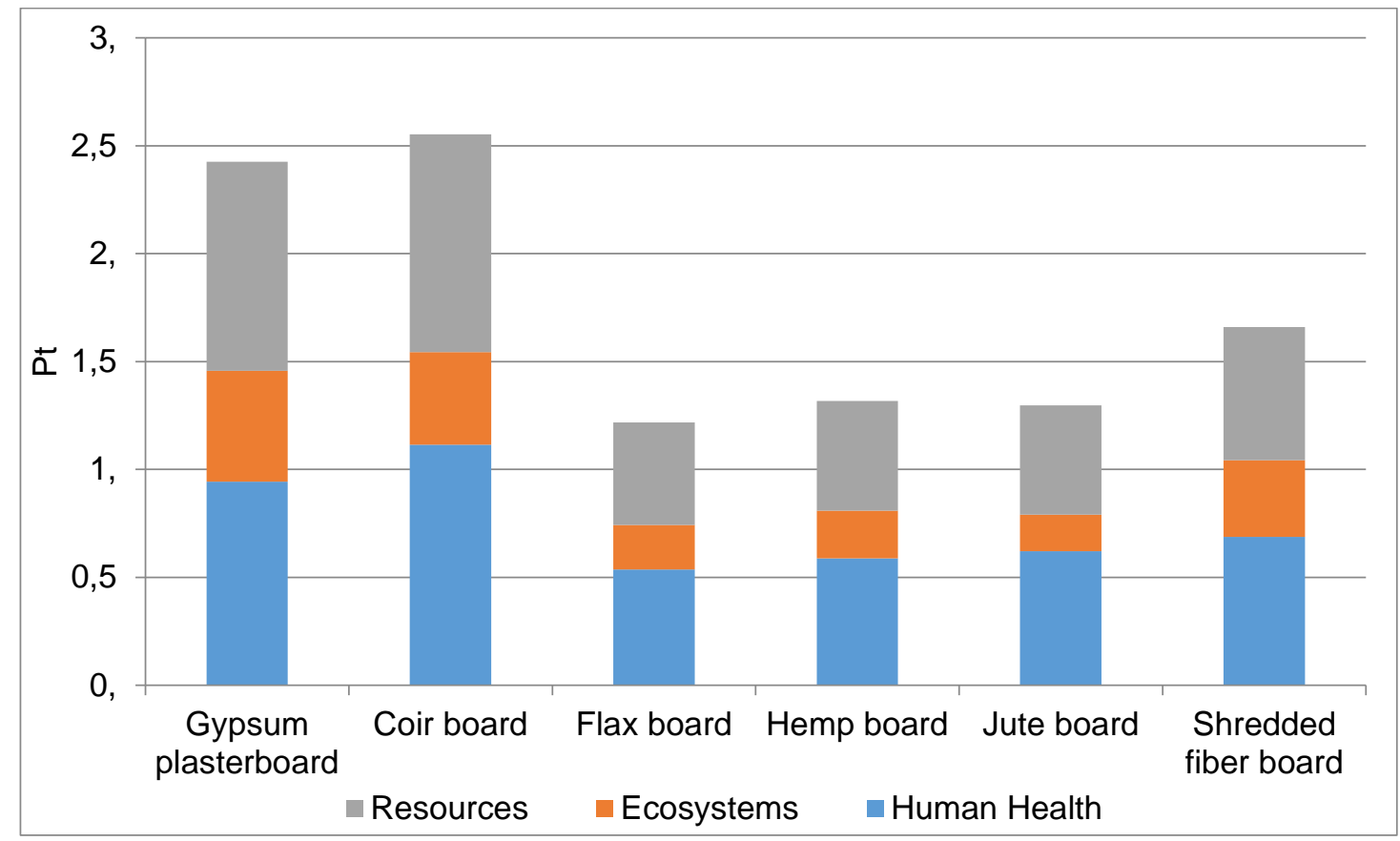

Fig.14. Single score result using the Recipe Endpoint $(H)$ method. Comparative analysis of the environmental impacts produced by a $1 \mathrm{~m}^{2}$ board

\section{3- Fiber impact comparison}

Once the results have shown that the Supersap epoxy composites are an all-around less environmentally impacting alternative to the gypsum plasterboard, a comparison between the fibers used in the composites is advisable. In order to perform the calculations, only the fiber cultivation and manufacturing process have been taken into account. Therefore considering the scope of the calculations from the cradle to the gate. 


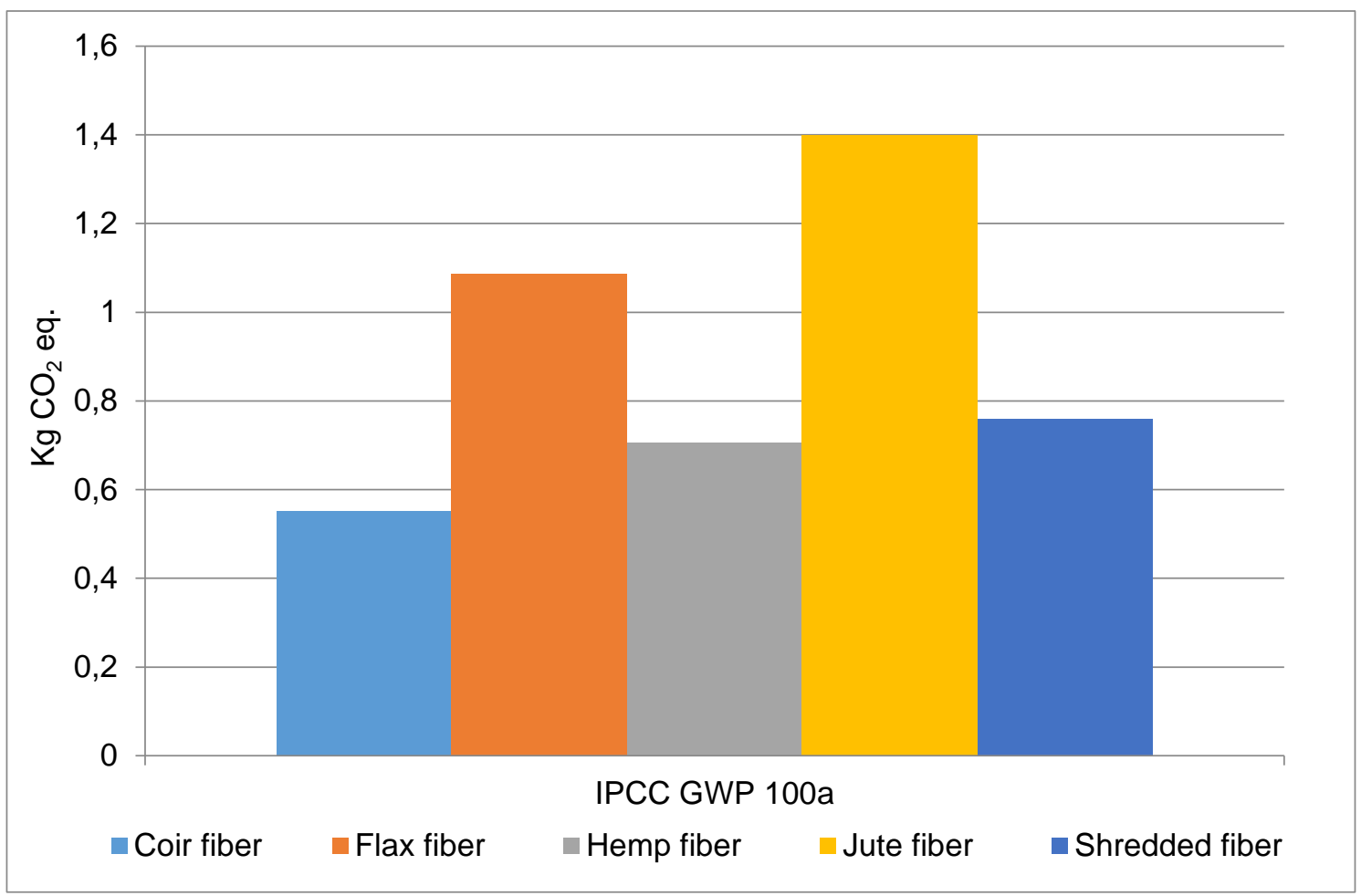

Fig.15 Comparative assessment of the carbon dioxide emitted by each fiber

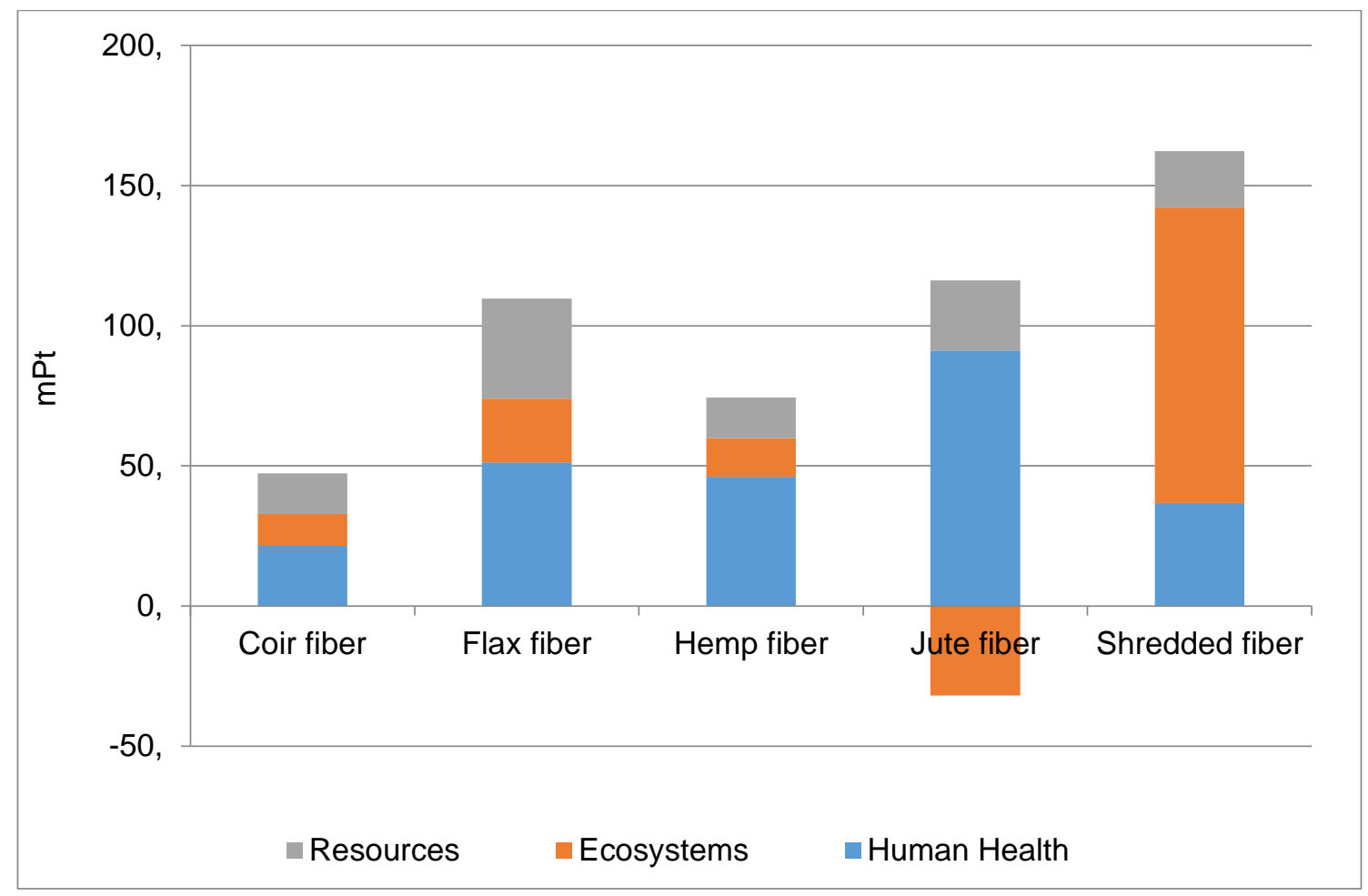

Fig.16 Single score result of each fiber. IPCC.GWP 100a. method. Comparative analysis of the environmental impacts produced by each fiber 
As seen in Figure 15, there is a distinguishable difference between the $\mathrm{CO}_{2}$ generated by flax fiber and jute fiber the other ones. Figure 16 shows a similar pattern in all the fibers except the Shredded cotton, which turns out to be the all-around most impacting fiber. Despite that fact, it is important to state that those impacts results are small compared to those generated by the Supersap Epoxy resin. Moreover the coir fiber is the one with the lowest impacts in both methods while the whole coir composite ends up being the most impacting one.

\section{4.-Conclusions}

This LCA study analyzed and compared the environmental impacts generated by different types of boards with application in the construction market from cradle to grave. The main objective was to determine whether the impacts generated by new natural fiber epoxy based composites are lower or higher than the ones emitted by the gypsum plasterboard.

The LCA is performed using two different highly trusted methods, the IPCC. GWP 100a and the Recipe Endpoint methods. Throughout analysis of the result obtained by the two methods, it is concluded that the use of natural fiber epoxy-based composites with Supersap Resin reduce the environmental impact in every category analyzed. In the case of carbon emissions calculated through the IPCC. GWP 100a the emissions are reduced from $40 \%$ in the case of the shredded cotton board up to $60 \%$ in the case of the flax board. When the calculations are performed using the Recipe Endpoint method, the difference between the gypsum plasterboard and the composites vary from 31 per cent to 50 per cent, depending on the natural fiber used, with respect to the gypsum plasterboard. The composites obtained lower impact results in resources, ecosystems and human health separately. The only exception is the coir board which has an impact over the environment very similar to the one generated by the gypsum plasterboard.

Besides, a comparison between the different fibers used in the composite is also carried out, coming to the conclusion that the fiber used does not represent a significant difference because of the low environmental impact of them all with respect to the other materials.

This paper shows the necessity of further research into new construction materials with low environmental impact that could replace traditional ones with guarantees.

Although this case study was performed for the Spanish market, the results could be applicable to any other region, considering that the impacts associated to the transport and electricity emissions don't represent a big percentage in the total.

\section{1- Further research opportunities}

The study of those factors outside the scope of this article need to be assessed in the near future. The recycling capabilities of the Supersap Epoxy resin are yet to be considered and could be a cornerstone of the market opportunities in the building market for this material. Further research may also include a detailed analysis of the disposal scenarios, considering different possibilities such as landfilling with energy recovery and incineration of the composites as a fuel. Additionally, the possibility of incineration with energy recovery could be an eco-friendly solution due to the high 
organic content of the composite. The reuse of the assembled composites is something to bear in mind as well.

The acoustic and thermal characteristics of the material will be evaluated as a part of this project in the short-term.

\section{5. - Acknowledgements}

The authors gratefully thank the Spanish Ministry of Economy, Industry and Competitiveness, for funding the project BIA2013-41537-R (BIAEFIREMAT 'Development of new sustainable eco-materials and building systems for the building industry, based on the use of residues and renewable raw materials'). The project is co-funded by the European Regional Development Fund and it is included in the R+D National Programme for Research Aimed at the Challenges of Society.

\section{6. - References}

Alves, C., Ferrão, P.M.C., Silva, A.J., Reis, L.G., Freitas, M., Rodrigues, L.B., Alves, D.E., 2010. Ecodesign of automotive components making use of natural jute fiber composites. J. Clean. Prod. 18, 313-327. doi:10.1016/j.jclepro.2009.10.022

Asdrubali, F., Schiavoni, S., Horoshenkov, K., 2012. A review of sustainable materials for acoustic applications, Building Acoustics. doi:10.1260/1351-010X.19.4.283

Boyle, A., Martin, C.J., Neuner, J.D., Corporation, H., 2001. Epoxy Resins. ASM Handb. 21, 78-89.

Cabeza, L.F., Rincón, L., Vilariño, V., Pérez, G., Castell, A., 2014. Life cycle assessment (LCA) and life cycle energy analysis (LCEA) of buildings and the building sector: A review. Renew. Sustain. Energy Rev. 29, 394-416. doi:10.1016/j.rser.2013.08.037

Cicala, G., Rosa, D. La, Musarra, M., Saccullo, G., Banatao, R., Pastine, S., Cicala, G., Rosa, D. La, Musarra, M., Saccullo, G., Pastine, S., 2016. Recyclable epoxy resins: An example of green approach for advanced composite applications Recyclable Epoxy Resins: an example of green approach for advanced composite applications. AIP Conf. Proc. 20027. doi:10.1063/1.4949602

Cox, P.M., Betts, R. a, Jones, C.D., Spall, S. a, Totterdell, I.J., 2000. Acceleration of global warming due to carbon-cycle feedbacks in a coupled climate model. Nature 408, 184-187. doi:10.1038/35041539

Deng, Y., Paraskevas, D., Tian, Y., Van Acker, K., Dewulf, W., Duflou, J.R., 2016. Life cycle assessment of flax-fibre reinforced epoxidized linseed oil composite with a flame retardant for electronic applications. J. Clean. Prod. 133, 427-438. doi:10.1016/j.jclepro.2016.05.172

Dusek, K., 1985. Epoxy resins and composites. Vol. 1. Berlin: Springer, cop. 1985., Berlin.

Ecoinvent, 2016. Database V3.3 [WWW Document]. URL http://www.ecoinvent.org/ (accessed 4.4.17).

Ekvall, T., 2001. Allocation in ISO 14041 - a critical review. J. Clean. Prod. 9, 197208.

Entropy Resins delivers sustainable composites, 2011. . Reinf. Plast. 55, 24. doi:10.1016/S0034-3617(11)70212-0 
European Commission - Joint Research Centre - Institute for Environment and Sustainability, 2010. General guide for Life Cycle Assessment - Detailed guidance, International Reference Life Cycle Data System (ILCD) Handbook. doi:10.2788/38479

González-Vallejo, P., Marrero, M., Solís-Guzmán, J., 2015. The ecological footprint of dwelling construction in Spain. Ecol. Indic. 52, 75-84. doi:10.1016/j.ecolind.2014.11.016

Hammami, a., Gebart, B.R., 2000. Analysis of the vacuum infusion molding process. Polym. Compos. 21, 28-40. doi:10.1002/pc.10162

International Organization for Standardization, 2006. Environmental management -Life cycle assessment -- Principles and framework [WWW Document]. URL https://www.iso.org/standard/37456.html (accessed 4.3.17).

John, M.J., Thomas, S., 2008. Biofibres and biocomposites. Carbohydr. Polym. 71, 343-364. doi:10.1016/j.carbpol.2007.05.040

La Rosa, A.D., Cozzo, G., Latteri, A., Mancini, G., Recca, A., Cicala, G., 2013. A comparative life cycle assessment of a composite component for automotive. Chem. Eng. Trans. 32, 1723-1728. doi:10.3303/CET1332288

La Rosa, A.D., Recca, A., Gagliano, A., Summerscales, J., Latteri, A., Cozzo, G., Cicala, G., 2014. Environmental impacts and thermal insulation performance of innovative composite solutions for building applications. Constr. Build. Mater. 55, 406-414. doi:10.1016/j.conbuildmat.2014.01.054

La Rosa, A.D., Recca, G., Summerscales, J., Latteri, A., Cozzo, G., Cicala, G., 2014. Bio-based versus traditional polymer composites. A life cycle assessment perspective. J. Clean. Prod. 74, 135-144. doi:10.1016/j.jclepro.2014.03.017

Le Duigou, A., Davies, P., Baley, C., 2011. Environmental impact analysis of the production of flax fibres to be used as composite material reinforcement. J. Biobased Mater. Bioenergy 5, 153-165. doi:10.1166/jbmb.2011.1116

Le Quéré, C., Moriarty, R., Andrew, R.M., Canadell, J.G., Sitch, S., Korsbakken, J.I., Friedlingstein, P., Peters, G.P., Andres, R.J., Boden, T.A., Houghton, R.A., House, J.I., Keeling, R.F., Tans, P., Arneth, A., Bakker, D.C.E., Barbero, L., Bopp, L., Chang, J., Chevallier, F., Chini, L.P., Ciais, P., Fader, M., Feely, R.A., Gkritzalis, T., Harris, I., Hauck, J., Ilyina, T., Jain, A.K., Kato, E., Kitidis, V., Klein Goldewijk, K., Koven, C., Landschützer, P., Lauvset, S.K., Lefèvre, N., Lenton, A., Lima, I.D., Metzl, N., Millero, F., Munro, D.R., Murata, A., S. Nabel, J.E.M., Nakaoka, S., Nojiri, Y., O'Brien, K., Olsen, A., Ono, T., Pérez, F.F., Pfeil, B., Pierrot, D., Poulter, B., Rehder, G., Rödenbeck, C., Saito, S., Schuster, U., Schwinger, J., Séférian, R., Steinhoff, T., Stocker, B.D., Sutton, A.J., Takahashi, T., Tilbrook, B., Van Der Laan-Luijkx, I.T., Van Der Werf, G.R., Van Heuven, S., Vandemark, D., Viovy, N., Wiltshire, A., Zaehle, S., Zeng, N., 2015. Global Carbon Budget 2015. Earth Syst. Sci. Data 7, 349-396. doi:10.5194/essd-7-349-2015

Parmesan, C., Yohe, G., 2003. A globally coherent fingerprint of climate change impacts across natural systems. Nature 421, 37-42. doi:10.1038/nature01286

Pascual-González, J., Guillén-Gosálbez, G., Mateo-Sanz, J.M., Jiménez-Esteller, L., 2016. Statistical analysis of the ecoinvent database to uncover relationships between life cycle impact assessment metrics. J. Clean. Prod. 112, 359-368. doi:10.1016/j.jclepro.2015.05.129

Pegoretti, T.D.S., Mathieux, F., Evrard, D., Brissaud, D., Arruda, J.R.D.F., 2014. Use of 
recycled natural fibres in industrial products: A comparative LCA case study on acoustic components in the Brazilian automotive sector. Resour. Conserv. Recycl. 84, 1-14. doi:10.1016/j.resconrec.2013.12.010

Rodríguez, G., Medina, C., Alegre, F.J., Asensio, E., De Sánchez Rojas, M.I., 2015. Assessment of Construction and Demolition Waste plant management in Spain: In pursuit of sustainability and eco-efficiency. J. Clean. Prod. 90, 16-24. doi:10.1016/j.jclepro.2014.11.067

Thomas, C.D., Thomas, C.D., Cameron, A., Cameron, A., Green, R.E., Green, R.E., Bakkenes, M., Bakkenes, M., Beaumont, L.J., Beaumont, L.J., Collingham, Y.C., Collingham, Y.C., Erasmus, B.F.N., Erasmus, B.F.N., De Siqueira, M.F., De Siqueira, M.F., Grainger, A., Grainger, A., Hannah, L., Hannah, L., Hughes, L., Hughes, L., Huntley, B., Huntley, B., Van Jaarsveld, A.S., Van Jaarsveld, A.S., Midgley, G.F., Midgley, G.F., Miles, L., Miles, L., Ortega-Huerta, M. a, OrtegaHuerta, M. a, Peterson, a T., Peterson, a T., Phillips, O.L., Phillips, O.L., Williams, S.E., Williams, S.E., 2004. Extinction risk from climate change. Nature 427, 145-8. doi:10.1038/nature02121

Tommie Ponsioen, 2015. Finding Your Way In Allocation Methods | PRé Sustainability [WWW Document]. www.pre-sustainability.com. URL https://www.presustainability.com/finding-your-way-in-allocation-methods-multifunctionalprocesses-recycling (accessed 2.6.17).

Wernet, G., Bauer, C., Steubing, B., Reinhard, J., Moreno-Ruiz, E., Weidema, B., 2016. The ecoinvent database version 3 (part I): overview and methodology. Int. J. Life Cycle Assess. 21, 1218-1230. doi:10.1007/s11367-016-1087-8 